ルチル粉末およびこれより製作した単結晶中の希土類含有量の 分光分析による結果を表 1 に示す。単結晶は全体を粉硉し，よく 混和して分析サンプルとした。ユーロピウム拉よびガドリニウム については原料中濃度よりも結晶中濃度が大となっているが，こ れは分析誤差によるものと考えられ, 分析值は希土類含有量のめ やすすを示しているものとみなされる。

\section{$3 \cdot 3$ 比抵抗分布}

酸素欠陥をもつ還元されたルチルはn 型半導性を示すことが知 られている ${ }^{8)}$ 。成長した単結晶の成長方向の比抵抗分布を四端子

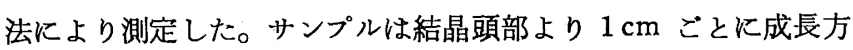

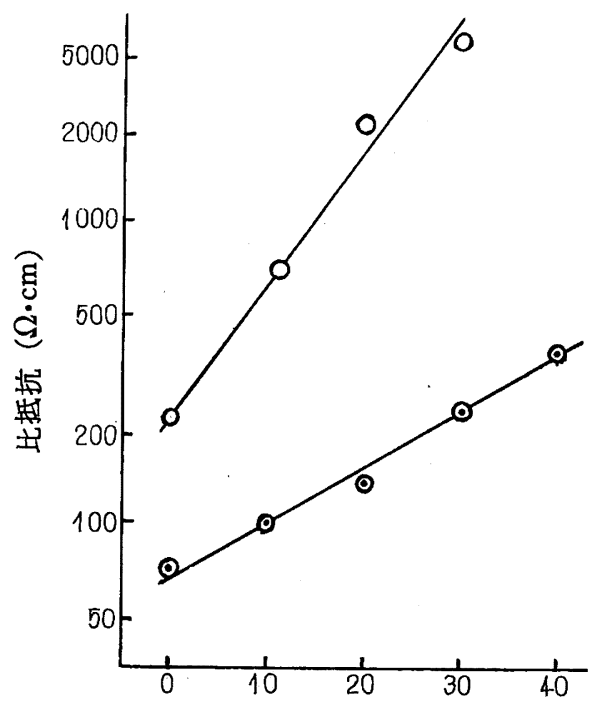

結晶頭部よりの距離 $(\mathrm{mm})$

図 5 成長軸方向の比抵抗分布
向に垂直に切断し，断面をアランダム研磨脷で研磨したのち，中 央部分の比抵抗を測定した。比抵抗値は同一種類の結晶でも酸水 素炎中の成長位置, 酸水素供給量, 供給比等によって異なり, 特 に含有する希土類によると考えられる差はみとめられなかった。 いずれの結晶に执いても比抵抗值は成長方向に沿ってほぼ指数曲 線にのるように分布していることが認められた（図 5 )。

\section{4 光吸収}

純粋なルチルは室温で波長 $410 \mathrm{~m} \mu$ 付近に吸収端をもち，こ れより $7 \mu$ までの光を透過することが知られている8)。

成長結晶を空気中で $700^{\circ} \mathrm{C}, 12$ 時間以上熱処理すると酸素欠 陥がなくなり全体が黄色透明の結晶となる。この結晶から薄片を きりとり，ベックマン型分光光度計により $220 \sim 3,000 \mathrm{~m} \mu$ の間 で光吸収を調べた。その結果, 希土類を含有したルチルの光吸収 曲線と純粋なルチルの光吸収曲線との間に差異は認められなかっ た。

\section{4 結 言}

市販ルチル粉末を用いて，ベルヌーイ法により 2 重管バーナー を使用し $0.1 \sim 0.2 \%$ のサマリウム, ニーロピウム，ガドリニウ ムを含有したルチル単結晶を製作した。希土類を含有した結晶と 純粋なルチル結晶との間に, 外見および比抵抗, 光吸収について 常温では特に差異はみとめられなかった。

今後, えられた結晶について ESR その他の物性測定について, ひきつづき実験を行なら予定である。

(昭和 37 年 4 月, 日本化学会第 15 年会一部講演)

おわりに本研究を行ならにあたり御指導をいただいた石川基礎 研究所長ならびに実験に協力された諸氏に感謝の意を表します。

電界発光用硫化垔鉛螢光体の製作

(昭 和 37 年 7 月 2 日 受 理)

松尾昂利*

EL 用硫化亜鉛虽光体の㥿作条件の発光に及ぼす影響を調べ，発光の効率を高めることを試みた。蛍光体としては発光 中心として $\mathrm{Cu}-\mathrm{Cl}$ 拈よび $\mathrm{Cu}-\mathrm{Al}$ をもつ二つのタイプについて研究した。蛍光体が $\mathrm{EL}$ を示すために必要な電導相は高 温から徐冷された際に有効に形成された。融剤として，塩化カルシウムを用いることにより，強い発光が得られ，さら に鉛を付加的に添加することは発光の青色成分を強め輝度を高めるのに役立った。

一方, 青色を多く含有する蛍光体では励起が強められると考えられ，これにしたがって共付活剤としてアルミニウムの 他に塩素を同時に作用させ，この塩素により青色中心の形成に笴与せしめた結果，予期以上に発光の強い蛍光体が得られ た。

\section{1 緒 言}

電界発光 (EL) は営光体を電界中に拁いたとき発光する現象で あり，この現象を大別すると，電極から蛍光体内に電荷の出入が める場合とない場合とに分けることができる。後者は真性 EL と 呼ばれて現在のところ実用的に重要なものと考えられている。そ して，この真性 EL を顕著に示す蛍光体としては現在銅で付活さ れた硫化亜鉛系に限られている。

* 松下電子工業株式会社研究所 : 高梘市大字西五百住.
電界による発光中心の励起過程としては硫化亜鉛結晶表面から 注入された, あるいはトラップから電導帯に引き上げられた電子 が電界により加速され，十分な運動のエネルギーを持って発光中 心に衝突して励起するという過程が最も妥当な考え方として認め られている。

電子が発光中心を励起できるエネルギーを得るには絶緑破壊を 起す程度の電界が必要である。しかし結晶が破壊を起さないため には，加えられた電界が局部的に集中するような高抵抗の部分が 存在しなければならない。このような高抵抗の場所として Mott- 
Schottky 型の欠乏層が考えられている。かかる堰層が結晶の表 面付近で形成されるためには，硫化亜鉛結晶が電導度の高い相と 接触していることが必要である。硫化亜鉛蛍光体では付活剂とし て銅を多量に加光約 $0.1 \%$ 程度にすると EL を示すようにな る。加えられた銅の一部は結晶内に溶けこんで発光中心を形成し ているが，残りは結晶の表面付近に硫化銅のような電導性の第二 相を形成していると考えられる1,2)。

以下，本報文では真性 EL を示す硫化亜鉛蛍光体について，蛍 光体の製作の条件がいかに蛍光体の性質に影響するかを調べると ともに, 明るいEL を示す蛍光体を得るための条件について研究 した結果を述べる。

\section{2 螢光体の焼成法と試験法}

精製した硫化亜鉛に添加物と融剤とを加えて焼成した。添加物 は硫酸銅, 硝酸鉛, 硝酸アルミニウムの形で, また融剤は塩化ナ トリウム, 塩化アンモニウム, 塩化カルシウムを水溶液にして硫 化亜鉛に加えた。試料はタンマン型ルシボ（内径 $2 \mathrm{~cm}$, 長さ 12 cm) に入れ，これをさらに然㜔管中に入れて電気炉で加熱した。 気流は細管を通してルッボ内へ送りこんだ。

焼成された試料は $10 \%$ 酢酸溶液で煮沸して酸化物を除き，つ ぎに 5\% シアン化カリ溶液で洗って遊離状の硫化銅を除いた。

蛍光体の EL の強さを試験するためのセルの構造は透明電導被 膜をほどこしたガラス板上に，尿素樹脂中に螢光体を体積比 33 \%で分散させた厚さ $50 \mu$ の膜をつくり，これに絶縁性を高め るために $25 \mu$ のマイラフィルムをのせ, その上にアルミニウム 䇴を貼って電極とした。そしてシリコーン油を用いてこれら相互 を接触させた。

このセルに $1000 \mathrm{~V}$ の正弦波電圧を印加し，この時の発光を， 光電池に視感度補正を施した煇度計にて測定した值を輝度として 表わした。

一方, ホトルミネセンス (PL) はアルミニウム板上に 約 0.1 $\mathrm{g} / \mathrm{cm}^{2}$ の厚さに蛍光体を沈着した試料に紫外線を当て, 同様に輝 度計にて受光して測定した。

発光エネルギースペクトルの測定は分光光電光度計を用いて試 料の発光と標準電球の光との交照により行なった。

\section{3 硫化亜鉛：銅，塩素系螢光体}

\section{$3 \cdot 1$ 電導相の形成}

蛍光体が EL を示すために必要な電導相の形成に関して表 1 の ような実験を行なった。共付活剤の塩素を供給する融剤として塩 化カルシウムを塩素に関して 3\% (重量) 加え, 密閉された空気 中 $950^{\circ} \mathrm{C}$ でいずれる 30 分間加熱した。

\begin{tabular}{|c|c|c|c|c|}
\hline \multirow{3}{*}{ 租 } & \multirow[b]{3}{*}{ 成 } & \multirow[t]{2}{*}{ 表 } & 1 & \multirow[b]{2}{*}{ 度 } \\
\hline & & & 辉 & \\
\hline & & 坌却 & EL $(500 \mathrm{c} / \mathrm{s})$ & PL $(365 \mathrm{~m} \mu)$ \\
\hline \multicolumn{2}{|c|}{$\mathrm{Cu}: 0.15 \%$} & 徐冷 & 40.0 & 83.6 \\
\hline \multicolumn{2}{|c|}{$\mathrm{Cu}: 0.15 \%$} & 急冷 & 2.4 & 59.6 \\
\hline \multicolumn{2}{|c|}{$\mathrm{Cu}: 0.3 \%$} & 急冷 & 12.0 & 66.8 \\
\hline
\end{tabular}

※1 この \% の単位は, $\mathrm{ZnS} 1 \mathrm{~mol}$ に対して $10^{-2} \mathrm{~mol}$ の割合 を意味し，以後これに従 5。

1) G. Diemer, P.Zalm, Physica 22, 561 (1956).

2) G. Destriau, Symposium on Luminescence Polytechnic Institute of Brooklyn (1955).
この結果によると PL の相造に比べて EL の相違は遙かに大 きく，発光スペクトルについては大きな变化は認められなかった から，EL の相違は主として電導相の形成によるものと考觉るこ とができる。付活剤の量が多いときには急冷しても ELは強くな るが, 徐冷することにより一㬝強められる。このことは徐泠によ って過剩の付活剤が析出されるような機構により一層有効に電導 相が形成されるものと考劣ることができる。

\section{$3 \cdot 2$ 融剤の種類}

融剤として 3 種類の代表的な塩化物, 寸なわち塩化アンモニウ ム, 塩化ナトリウム拈よび塩化カルシウムを用いて蛍光体を焼成 し，それらの効果を調べた。付活剤は銅を $0.15 \%$ とし，融剤の 量は塩素について $1 \%$ とした。焼成は $950^{\circ} \mathrm{C}, 30$ 分間であり, 徐冷した。得られた蛍光体の発光の強さおよび洗浄後の残留して いる銅拉よび塩素の分析值を表 2 に示す。また，この 3 種の蛍光 体の EL 発光スペクトルを図 1 に示した。なお，融剤の量が $5 \%$ の場合の結果も $1 \%$ の場合と同じ傾向を示し, EL の強さのみが $1 \%$ の場合より全体に低かった。

\begin{tabular}{|c|c|c|c|c|}
\hline \multirow[b]{2}{*}{ 融 浏 } & 表 & 2 & \multirow[b]{2}{*}{$\begin{array}{c}\mathrm{Cu} \text { 分析値 } \\
(\%)\end{array}$} & \multirow[b]{2}{*}{$\begin{array}{c}\mathrm{C1} \text { 分析做 } \\
(\%)\end{array}$} \\
\hline & EL $(500 \mathrm{c} / \mathrm{s})$ & PL $(365 \mathrm{~m} \mu)$ & & \\
\hline $\mathrm{NH}_{4} \mathrm{Cl}$ & 20.5 & 18 & 0.05 & 0.02 \\
\hline $\mathrm{NaCl}$ & 33 & 26 & 0.05 & 0.02 \\
\hline $\mathrm{CaCl}_{2}$ & 61 & 28 & 0.07 & 0.03 \\
\hline
\end{tabular}

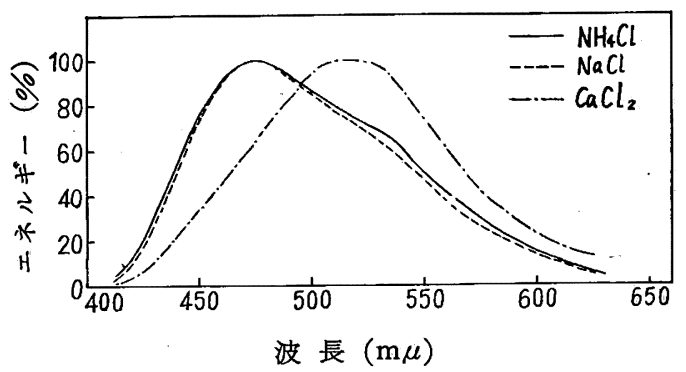

図 1 融剤の種類と発光スペクトルの関係

これらの結果より EL に関する限りでは 3 種類の融剤の中, 塩 化カルシウムが最も好都合であることになる。この場合は結晶内 に溶けこむ塩素の量が多く，したがって銅の量も多い。このこと はこの場合に発光スペクトルに拈いて緑色成分が多く青色成分が 少ないことからも理解できる。冷却過程で付活剂が析出するには 高温における固溶限度まで付活剂が溶けこんでいる必要がある。 塩化カルシウムを用いた場合と他の場合との EL の強さの相違は 高温における付活剤の濃度に相違があるものと考えることにより 説明できる。

そこで塩化カルシウムについてその添加量と発光強度の関係を 測定し表 3 の結果をえた。添加量は輝度に大きく影響するが，発 光スペクトルには影響が小さいから融剤の量は電導相の形成に関 係することを意味する。すなわち, 銅は塩素とともに結晶内に溶 けこんで高い濃度に発光中心をつくることが必要であるが，一方 冷却の過程で, 適当に塩素が除かれれば過剩の銅の析出が促進さ れて電導相がつくられるのであろう。そのため, 添加する融剤の

\begin{tabular}{|c|c|c|c|c|c|}
\hline \multirow[b]{2}{*}{$\mathrm{CaCl}_{2}$ 添加量 $(\%)$} & 表 & \multicolumn{2}{|c|}{3} & \multirow[b]{2}{*}{2.0} & \multirow[b]{2}{*}{3.0} \\
\hline & 0.5 & 1.0 & 1.5 & & \\
\hline $\mathrm{B}_{200^{*}}$ (相対値) & 0.65 & 1.0 & 1.55 & 1.50 & 1.40 \\
\hline $\mathrm{B}_{2000} / \mathrm{B}_{200}$ (相対値) & 0.99 & 1.0 & 1.04 & 1.10 & 1.06 \\
\hline
\end{tabular}


量には適当な值が存在することになる。

\section{$3 \cdot 3$ 鉛添加の効果}

銅とともに鉛を添加することにより強いELを示す蛍光体の兄 られることが Homer らにより報告されている3)。

3 種類の異なった銅の量に対して鉛の添加量を変えた実験を行 なった。焼成を 2 段階に分けて，第 1 段では銅の及を添加して融 剂とともに焼成し，第 2 段で鉛を加兄て燒成した。温度および時 間は第 1 段が $950^{\circ} \mathrm{C}, 30$ 分間, 第 2 段は $850^{\circ} \mathrm{C}, 30$ 分間の加熱 の後徐冷した。使用した融剤は塩化カルシウム $1 \%$ である。困 2 飞L の強度を示し, 図3に $1000 \mathrm{c} / \mathrm{s}$ で励起したときの発光 スペクトルを示す。この結果から鉛の添加が輝度の向上に有効で

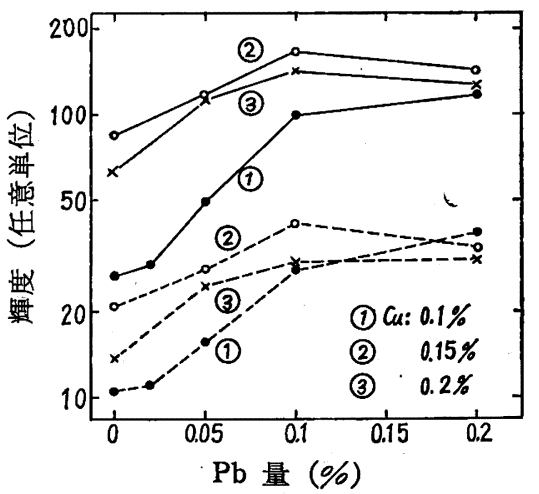

図 $2 \mathrm{~Pb}$ 量と輝度の関係 点線 : $200 \mathrm{c} / \mathrm{s}$ 励起 点線 $: 1000 \mathrm{c} / \mathrm{s}$ 炀起

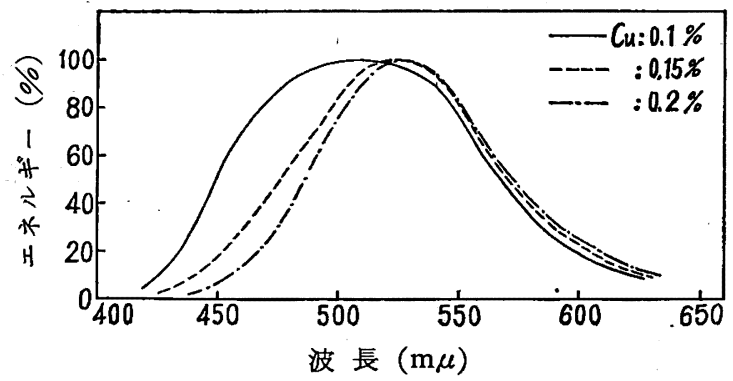

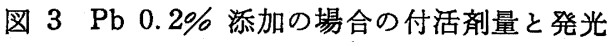
スペクトルの関係 $(1000 \mathrm{c} / \mathrm{s}$ 励起 $)$

あることがわかる。そして鉛の量の増加とともに輝度が向上し約 $0.1 \%$ 程度で飽和する。鉛を含まない場合, 融剤に塩化カルシウ ムを用いれば青色成分は極めて少なく，また銅量に関係なく，ほ とんど変化しないが，鉛をもつ場合はいずれも青色成分が增加し 銅量の少ないほどその增加が著しい。Homer らは鉛が電導性物 質の析出を增進すると考之た ${ }^{8}$ 。結晶内に特ける緑色中心は銅-塩 素の対で形成されると考兄られて扣り，これは荷電補償の関係炕 おいて安定に存在する ${ }^{4}$ ) から，鉛が結晶内9塩素を奪 5 す と考 えれば，結晶内で銅が過㮃となり，それを一部は青色中心の形成 飞寄与し，他は結晶の表面または内部に析出すると考兄ることが できる。したがって鉛の添加の效果は青色発光の增加とともに輝 度の向上をもたらす。そして銅の多い場合は緑色中心の濃度が最 初から多いため，鉛添加による効果，特に青色中心の生成は顕著 飞現われない。

図 4 には銅量の異なる 3 種の蛍光体の EL の周波数特性を示し

3) H. H. Homer, R. W. Rulon, K. H. Butler, J. Electrochem. Soc. 100, 566 (1953).

4) F. A. Kröger, J. F. Hellingman, J. Electrochem. Soc. 93, 156 (1948) ; 95, 68 (1949).

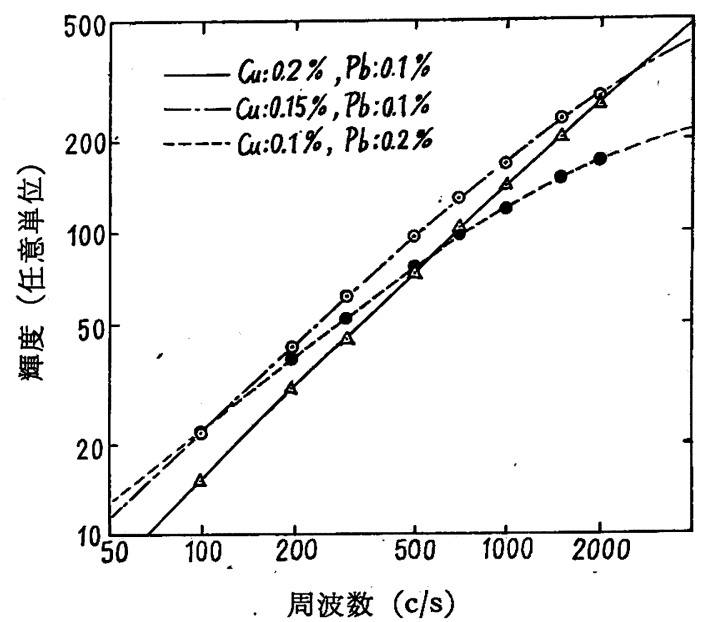

図 $4 \mathrm{~Pb}$ 添加の場合の付活剤量による周波数特性の比較 た。青色成分をむつものほど周波数の增加と共に緑色成分が飽和 するから，銅の少ないものは低周波域では輝度は高いにもかかわ らず周波数が高くなると輝度の飽和する傾向が強い。

\section{4 硫化亜塩 : 銅, アルミニウム系螢光体 ${ }^{5)}$}

このタイプの蛍光体ではアルミニウムが共付活凨となってやは り緑色の発光中心を形成する。EL を得るために有効な電導相の 形成については前章の硫化亜鉛：銅，塩素営光体の場合と本質的 に変りないはずである。

\section{$4 \cdot 1$ 焼成条件}

加熱の方法について表 4 のような実験結果を得た。このときの 試料の組成は $\mathrm{Cu}: 0.15 \%, \mathrm{Al}: 0.1 \%$ で雾团気は湿った硫化水 素気流で $0.3 \mathrm{l} / \mathrm{min}$ の流量とした。この結果から低温から徐熱 することが発光中心の形成に好都合であることがわかる。

\begin{tabular}{|c|c|c|c|}
\hline & 表 & \multirow[t]{2}{*}{4} & \multirow{3}{*}{$\mathbf{B}_{200}$} \\
\hline \multicolumn{2}{|c|}{ 加 } & & \\
\hline $900^{\circ} \mathrm{C}$ & ${ }_{1000^{\circ} \mathrm{C}}$ & $1100^{\circ} \mathrm{C}$ & \\
\hline $0.5 \mathrm{hr}$ & $0.5 \mathrm{hr}$ & $0.5 \mathrm{hr}$ & 22 \\
\hline 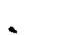 & 0.5 & 1.0 & 19 \\
\hline & & 1.5 & 14 \\
\hline & & 1.0 & 12 \\
\hline & & 2.0 & 19 \\
\hline & & 3.0 & 17 \\
\hline
\end{tabular}

純粋な硫化水素中で焼成されると発光が弱くなり，これを水素 雲囲気中で再焼成すると輝度が增加するが，最初から適当に水分 を含む硫化水素中で焼成した場合には高い輝度の営光体がえられ た。雾团気中の水分の量が輝度に招よぼす效果について実験し， その結果を表 5 に示した。この場合 wet の雾团気は $25^{\circ} \mathrm{C}$ の水 中を通した硫化水素ガスの気流, dry はこれを $0^{\circ} \mathrm{C} て ゙$ 冷却した トラップを通したるのである。dry-wet は烸成は dry で行ない， 冷却の過程を wet にしたことを意味する。流量はいずれる 0.15 $l / \mathrm{min}$ であり組成は $\mathrm{Cu} \mathrm{0.125 \% ，A1} \mathrm{0.1 \% である。}$

wet の場合はアルミナが硫化物に变わりにくいため，発光中心

\begin{tabular}{ccc} 
& 表 & 5 \\
繁围武 & $\mathbf{B}_{200}$ & $\mathbf{R}\left(\mathbf{B}_{\mathbf{2 0 0 0}} / \mathbf{B}_{\mathbf{2 0 0}}\right)$ \\
\hline wet & 14.5 & 6.2 \\
dry-wet & 34.4 & 7.0 \\
dry & 40.1 & 8.9
\end{tabular}

5) H. C. Froelich, J. Electrochem. Soc. 100, 496(1953) ; P.Zalm, Philips Res. Rep. 11, 353 (1956). 
の濃度が低い。dry-wet では冷却の過程でアルミナー硫化アル ミニウムの反応が再びもとにもどされ電導相の析出が増進される ことを予想したが，実際には発光中心の濃度が低くなって，むし ろ dry の場合より発光が低下した。dry の場合に执いても温度 により化学反応の向きが変化するはずであるから，一度結晶内に 硫化物となって溶けこんだアルミニウムは冷却の過程でふたたび 酸化物として結晶から除かれ，付活剤の析出が起る。したがっ て, この場合には発光中心の濃度と電導相の条件から, 高い輝度 がえられたのであろら。

\section{$4 \cdot 3$ 輝度向上の試み}

前章の結果によると銅の少ない程発光の青色成分が多くなり， 周波数の増加による輝度の飽和の傾向が強くなる。しかしながら 低周波域においてはむしろ輝度は高い。そこで青色成分の多い硫 化亜鉛：銅，塩素系蛍光体について，千涉フィルターによって発 光を青色成分 $(450 \mathrm{~m} \mu)$ と緑色成分 $(530 \mathrm{~m} \mu)$ とに分け，それ ぞれの挙動を調べた結果を図 5 に示した。周波数特性に执いて青 色成分が周波数に対して superlinear に増加し，緑色成分は周波 数により飽和の傾向を示すこと，拈よび図 6 に示される各発光成 分の温度特性において低温になるほど青色成分の増加すること等 を考えあわせてつぎのよ5に考えられる。青色中心は緑色中心よ り少なくとも電界励起に対する確率が高く励起の過程では青色中 心の寄与が大きい。そして青色中心に吸収されたエネルギーはそ れに続く過程で他の中心に伝達され，その一部は緑色中心に伝達 されて発光を生ずる。結局, 青色成分を多くもつ蛍光体では励起 が青色中心で強く起り，そのエネルギーが緑色中心に伝達されて 視感度の高い発光となるから, 輝度が高くなる。周波数が増加す るとェネルギーの伝達が起りにくくなり青色中心での発光が増加

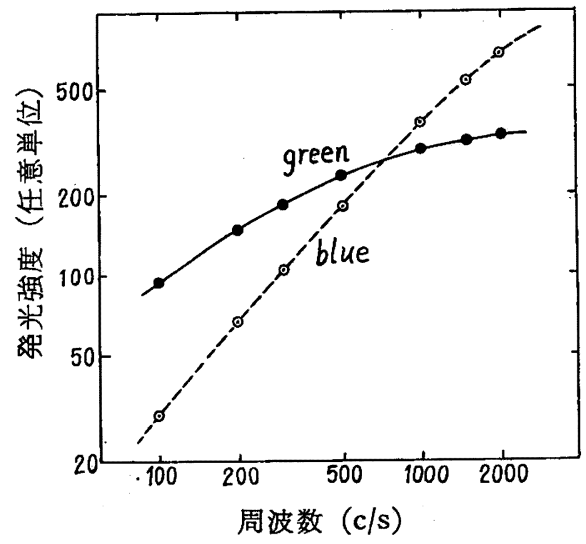

図 5 緑色および青色成分の周波数特性

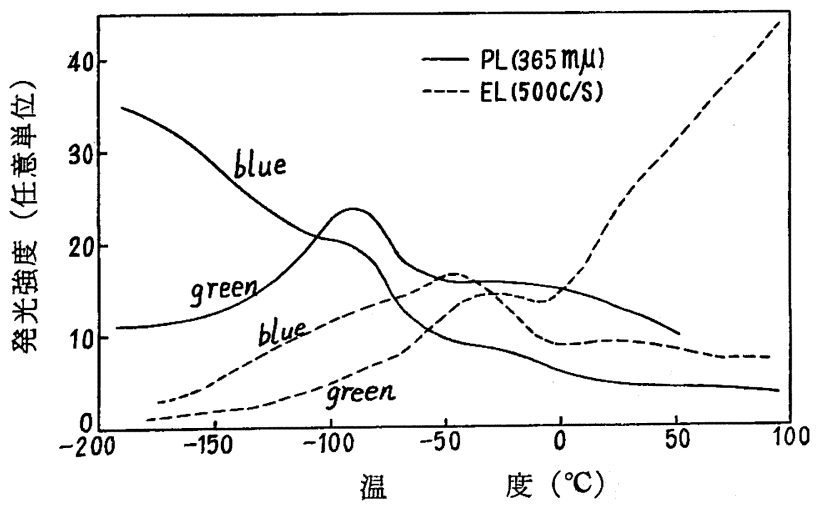

图 6 緑色扣よび青色成分の発光の温度特性
するが緑色成分が減少し輝度は低下する。

さらに考兄られる可能性としては青色中心が選択的に励起され れば堰層内の電界が強められることとなり，それに続く励起の強 度が高められることであり，あるいは，このよ5な青色中心が形 成されるような状態では電導相も有効仅形成されることである。

以上のような考方方を今の銅-アルミニウム型の 発光中心をも つ蛍光体にも適用した。結晶内に溶けこむアルミニウムの量を少 なくして結晶内での $[\mathrm{Cu}] /[\mathrm{Al}]$ 比を増大すれば青色中心の割合 が增加するが，実際には青色中心の励起に対する效果は大きくな w。

そこで銅-塩素系の場合の 類推から塩素の 存在の下で青色中心 を形成することを試み，一方で緑色中心は 銅ーアルミニウムの組 み合わせによって形成するものとした。実際の操作は付活剂を塩 化銅の形で加え，それに硝酸アルミニウムを加えた。加熱すれば 最初結晶内に $\mathrm{CuCl}$ の形で溶けこみ, 後次第にアルミニウムが硫 化物になって溶けこんできて同時に塩䋕は雾囲気中へ除かれ塩素 がアルミニウムに置換されてゆく。 $[\mathrm{Cu}]>[\mathrm{Al}]$ の条件の下では 塩素にもとづくと思われ る青色中心の存在するこ とが確認される。因 7 に は $[\mathrm{Cu}] /[\mathrm{Al}]$ の変化に 対する青色中心の割合の 変化を示す。このよ5に して形成された青色中心 は塩素を含まない場合に も認められる青色中心と

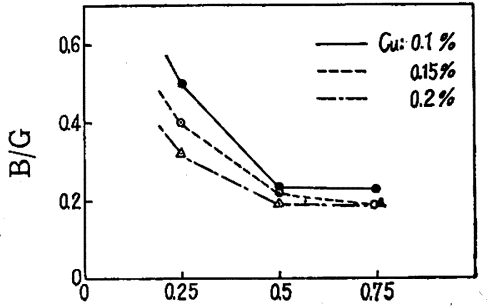

$[\mathrm{Al}] /[\mathrm{Cu}]$

図 $7[\mathrm{Al}] /[\mathrm{Cu}]$ と $\mathrm{B} / \mathrm{G}$ の関係 は性質が異なっている6。

このようにしてつくられた蛍光体，たとえば $\mathrm{CuCl}: 0.125$, $\mathrm{Al}: 0.1 \%$ を添加し $0^{\circ} \mathrm{C}$ のトラップを通した硫化水素気流中で 烧成された蛍光体と従来通りの組成にて焼かれた蛍光体の特性を 比較すると, 表 6 のようになる。

\begin{tabular}{|c|c|c|c|c|}
\hline 組 & & $\mathrm{B}_{200}$ & $\mathrm{R}\left(\mathrm{B}_{2000} / \mathrm{B}_{200}\right)$ & PL の減衰 \\
\hline & 1) A1 & 69.3 & 6.9 & $1 \mathrm{~ms}$ \\
\hline & $\mathrm{A} 1$ & 40.1 & 8.9 & 4 \\
\hline
\end{tabular}

これは明らかに顕著な効果を示して拾り，EL の輝度の向上は 著しい。この Rの值からもわかるように，青色成分も増加してい る。そして体色は淡く $365 \mathrm{~m} \mu$ 励起 PL の減衰は短かくなって いるから発光中心の濃度が高いことも予想できる。

かくして, 輝度の向 上が果たされたのでつ ぎに添加物の量を変化 し輝度を調べた。困 8 の結果により銅の量は $0.175 \%$ ，其付活剂は $[\mathrm{Al}] /[\mathrm{Cu}]=0.75$ で最 高の輝度がえられた。 ただしこの場合の輝 度は $1000 \mathrm{c} / \mathrm{s}$ での励

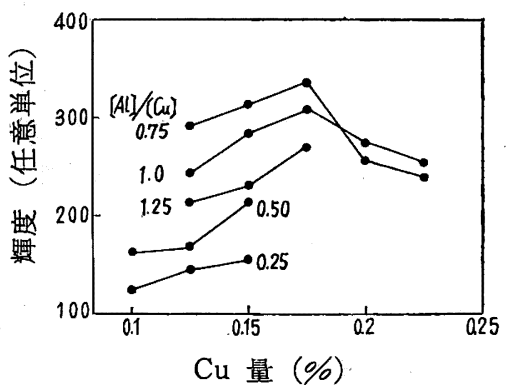

図 8 付活剤量と輝度の関係 起の值であり，この条件でえられた蛍光体では青色の濃度は一層 少なくなっているから図9に示すように $\mathrm{Cu}: 0.125 \%$ のものと

6）松尾，第 9 回応用物理学関係連合講演会予稿集 p. 216 . 


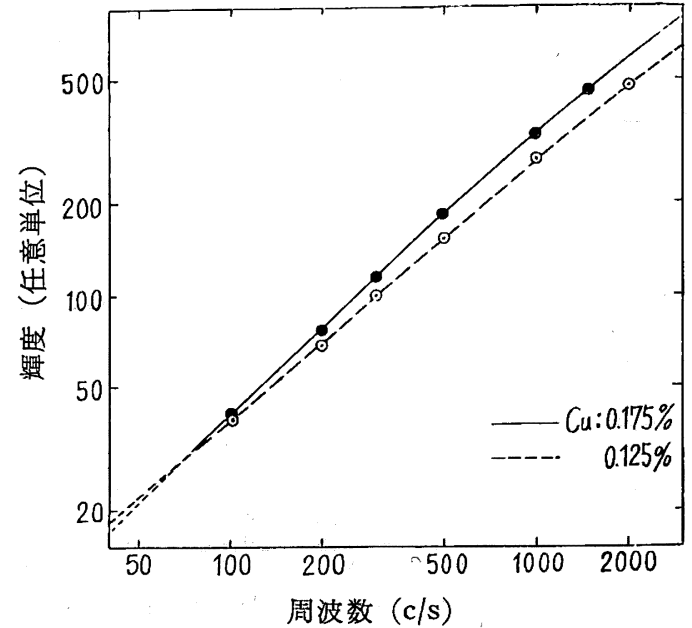

図 9 周波数特性の比較

比較すると低周波域では輝度の差は小さい。結局， $\mathrm{Cu}: 0.175 \%$ でえられた輝度の高い蛍光体では励起のかなりの部分を受けるつ ほど青色中心の割合が多くないとしても，励起の初期に拈いて堰 㬝内の電界を強めるような効果をもって全体の励起, したがって
発光を強めていることが考えられる。

\section{5 結 論}

蛍光体が EL を示すためには電導相が結晶の表面または内部に 形成される必要があり，その形成は高温において付活剤を十分に 結晶内に溶かし，これを冷却の過程で再び析出させることにより 有効に行なわれた。さらに銅一塩素系蛍光体に和いては，融剤と して塩化カルシウムがよいこと, その量が発光の強さに影響する こと，むるいは鉛の添加の効果等を明らかにした。

さらに程素の関与する青色中心は, 電界励起に対する確率が高 く, これの存在により全体の励起が強められ, したがって輝度が 高くなると予想した。共付活剤として，アルミニウムととるに塩 素を作用させ, 予想通りに, 発光の強い蛍光体をらることができ た。この種の蛍光体は, 国内外の同系の蛍光体と比へて発光が強 Wo

終りに，本研究について，ご指導をいただいた当所 奥村富三 郎博士，実験の協力をいただいた正司雅美，野耕治抗よびその 他の諸氏に深謝するとともに，有益なこ助言をいたたいた東北大 学教授 和田正信博士怙よび高橋 正博士に厚く御礼申し上げる。

\section{光導電性硫化カドミウムの応答特性}

(昭 和 37 年 7 月 2 日 受 理)

$$
\text { 及 川 充* }
$$

銅ならびに塩素をドープした硫化カドミウムに拉いて, 微結晶界面の存在が自由電子の寿命, 光電流の応答速度, およ び感度にいかに影響するかにつき検討した。

その結果, 電子の寿命時間は, 結晶中の銅の濃度に逆比例し, その自由電子に対する衝突断面積は約 $2 \times 10^{-24} \mathrm{~cm}^{2}$ と

いう小さな值であることが計算された。これから，結晶中にほほ均一に分布する銅が増感中心となり，再結合反応を支配 することがわかった。

また, 励起光の波長を, 硫化カドミウムの光学的吸収端より短波長のものと, 長波長のものの 2 種にかえ, そのさい光 電流の応答速度にあらわれる浅いトラップの効果を観測し，その分布状態をしらべた。

以上の諸結果から，このような試料では，再結合中心や，浅いトラップが，特に界面のみに集中して存在するるのでな く，結晶内にほぼ均一に分布していることがわかった。

また，光電流が印加電圧に対し，高次の函数関係にあること，ならびに減衰電流が，電圧の一時的消去によりクェンチ されることから，光電流值は界面に扣ける空間電荷層の状態により，ある程度制限されることを示した。

\section{1 緒 言}

著者らは, すでに前報1)に执いて, 硫化カドミりムの光電流の 立ち上り, 減哀の応答時間は, 再結合速度によって定められる自 由電子の寿命時間と, 自由電子が浅いトラップに落ち込んだり, またトラップから逃げ出したりすることによって生ずる時間沶く れとによって定められることを示した。

その際付活剂の銅の濃度と自由電子の寿命時間とが逆比例関係 にあること,ならびに銅の濃度の増加につれて浅い空のトラップ の濃度が増加することを見出した。これらの事実から，再結合中 心は銅によって形成されること，拈よび銅はこれと対をなして入 る塩素から電子を 1 個うばい， $\mathrm{Cu}^{+}$の状態で活性中心を形づく

* 日立製作所中央研究所：東京都武蔵野市。

1）及川，岡部，野々垣，工化 65,745 (1962).
り，また電子をうばわれた塩素は空の浅いトラップとして働くこ とを推定した。ただし，実験に用いた試料は，銅ならびに塩素に よって活性化された硫化カドミウム微結晶を合成樹脂で結着した 集合体であるので，応答速度などの諸特性に対する微結晶界面の 影響について，更に検討する必要のあることをのべて抽い。

今回は前報に続き，このような試料の諸特性に対する微結晶界 面の効果を追求する目的で行なった実験結果について報告する。

結晶表面には格子久陥や, 吸着分子が内部に比べ多数存在して いると考えられるのに，微結晶の集合体からなる試料について測 定した自由電子の寿命時間が，付活剤としての銅の濃度によって ほとんど定められ，結晶界面の効果が明らかには現われて来ない のはなぜか。浅いトラップの結晶に拈ける分布はどのような状熊 にめるか。光電流特性に対し微結晶界面の存在はどのような影響 をもたらすか，など以上の各項目について検討を加える。 